\title{
Toward a Reappraisal of the Bonds between Emotional Intelligence and Burnout
}

\author{
Parviz Alavinia (Corresponding author) \\ Faculty of Humanities and Letters, Urmia University \\ Vajfajr 2 Blvd., Urmia, West Azerbaijan, Iran \\ Tel: 98-0441-336-2008Ｅ-mail: pevinia2006@yahoo.com
}

\author{
Tala Ahmadzadeh \\ Maragheh Azad University \\ PO box 345, Shahid Derakhshi Blvd., Maragheh, Iran \\ Tel: 98-0421-325-4506_E-mail: sroo-_2008@yahoo.com
}

Received: January 19, 2012

doi:10.5539/elt.v5n4p37
Accepted: February 15, 2012

Published: April 1, 2012

\begin{abstract}
Though several researchers have thus far attempted to address the viable relationship between EI and burnout, it seems that few have approached the notion of burnout by considering the influence of teachers' coping resources such as EI especially in an EFL context. Thus, in an attempt to bridge this gap, the present study sought to explore the association between burnout and EI in a sample of 75 high school EFL teachers in West Azerbaijan. Successive to the administration of Maslach Burnout Inventory-Educators Survey (Maslach, Jackson, \& Leiter, 1996) and Bar-On's EQ-i (1997a, b), the data were analyzed through running Pearson Product-Moment Correlations, Regression analyses and Independent-Samples t-tests. The findings showed that EI was reversely correlated with burnout, and it could be a potent predictor of burnout. Also, in line with the gained upshots age and teaching experience were positively correlated with EI and reversely correlated with teacher burnout. Finally, significant differences among teachers' burnout (but not their EI) were found with respect to gender.
\end{abstract}

Keywords: Bar-On's EQ-i, EI, EQ, Burnout

Bar-On, R. (1997a). The Emotional Quotient Inventory (EQ-i): A test of emotional intelligence. Toronto: Multi-Health Systems.

Bar-On, R. (1997b). BarOn Emotional Quotient Inventory (EQ-i): Technical manual. Toronto: Multi-Health Systems.

Maslach, C., Jackson, S. E., \& Leiter, M. P. (1996). Maslach burnout inventory manual (3rd edition). Palo Alto, CA: Consulting Psychologist Press.

\section{Introduction}

\subsection{Overview}

Successive to the implementation of Kyriacou and Sutcliffe's (1978 a, b) seminal work, numerous studies have, to date, strived to deal with the notion of teacher stress (e.g., Farber 1984, 1991; Heibert \& Farber, 1984; Kyriacou, 1980). Owing to the high level of teacher attrition, teacher stress continues to feature as an important topic in educational research today. The notion of stress among teachers has now turned to a rather globalized issue, as roughly a third of the teachers surveyed in various studies around the world reported that they regarded teaching as highly stressful (Borg, 1990).

As Kyriacou (2001) states, "the stress experienced by a particular teacher will be unique to him or her, and will depend on the precise complex interaction between his or her personalities, values, skills, and circumstances" (p. 29). According to Milstein and Farkas (1988), though being faced with different kinds of stressors, i.e. stress-laden factors is an inseparable part of the teaching profession, teachers' reactions to the stress-inducing factors vary spectacularly. In other words, under stressful circumstances, different teachers are likely to respond in totally diverse manners ranging from mild frustration, anxiety, and irritability to emotional exhaustion as well as psychosomatic 
and depressive symptoms (Kyriacou \& Pratt, 1985). An extreme amount of chronic stress might eventually lead to burnout (Maslach, Jackson, \& Leiter, 1996) which, as Maslach (1993) contends, refers to a psychological syndrome being marked by emotional exhaustion, depersonalization, and reduced personal accomplishment that is viable to occur among individuals who work with other people in a particular capacity.

Not only does burnout have detrimental effects on the teacher's general sense of wellbeing as well as on his/her instructional attempts, but as the previous body of research helps reveal it can also negatively influence student performance; other long-term aftermaths of burnout might even include job dissatisfaction, work alienation, and finally teachers' leaving the profession. To be prepared to set out for a campaign against the harmful repercussions of burnout, the teachers are to be equipped with the means to fight against the so-called stressors, and a major asset for teachers seeking to cope with stress is said to be enjoying high level of emotional intelligence, i.e. "the ability to monitor one's own and other's feelings, to discriminate among them and to use this information to guide one's thinking and actions" (Salovey \& Mayer, 1990, p. 185). As Gohm, Corser, \& Dalsky (2005) point out emotional intelligence is associated with relatively lower reported stress levels. Yet, it goes without saying that individuals differ as to their abilities to practice effective control over their emotional lives, that is they enjoy varying levels of emotional intelligence (Salovey, Bedell, Detweiler, \& Mayer, 2000). But, then again, the heartwarming message is that the individuals' emotional intelligence is prone to betterment (e.g. Alavinia, 2009/2011a).

\subsection{Statement of the Problem and Significance of the Study}

The purpose of the present study is threefold. It investigates, first, whether there is any significant relationship between burnout and emotional intelligence among EFL teachers, second, whether emotional intelligence can significantly contribute to the prediction of burnout, and third, whether there is any significant difference in teachers' burnout, emotional intelligence and self efficacy with respect to demographic variables.

The literature on teacher role and performance is fraught with studies targeted at investigating the correlation between EI and burnout, on the one hand and various other variables such as teacher stress, pedagogical success, academic achievement, etc., on the other (e.g., Chan, 2006; Ghanizadeh \& Moafian, 2009a,b; Moafian \& Ghanizadeh, 2009; Paese, 2003; Rastegar \& Memarpour, 2009; Rydell \& Henricsson, 2004, to name only a few). Contrary to this wide coverage of issues and aspects relevant to the implications of EQ and burnout for different pedagogical perspectives, it still seems that few studies have strived to cast a simultaneous and hence profound look at how the interpolation of these two constructs might affect varied aspects of a teacher's instructional career. Therefore, what the current study seeks to accomplish is delving into a more indepth investigation of the go-togetherness between the teachers' EI level and their burnout. To this end, the following research questions were posited:

RQ1: Is there any statistically significant relationship between burnout and emotional intelligence among Iranian EFL teachers?

RQ2: Can emotional intelligence significantly predict burnout among Iranian EFL teachers?

RQ3: Is there any statistically significant relationship between emotional intelligence and burnout and the demographic variables?

RQ3A: Do teacher age and years of teaching experience have any statistically significant relationship with burnout and emotional intelligence among Iranian EFL teachers?

RQ3B: Is there any statistically significant difference among Iranian EFL teachers on their scores on emotional intelligence with respect to gender?

RQ3C: Is there any statistically significant difference among Iranian EFL teachers on their scores on burnout with respect to gender?

\section{Literature Review}

\subsection{Burnout}

Devised by Freudenberger (1974), burnout is taken to mean a certain kind of ongoing 'demoralization, disenchantment and disillusionment' which is said to be prevalent among the majority of workers, particularly those engaged with the provision of a particular type of long-term service or assistance for clients. Individuals involved in such taxing and demanding professions are hence said to be more prone to developing some undesirable feelings such as stress, frustration, overload, and despair, which in turn will give way to burnout. Successive to Freudenberger's seminal work in the area of burnout, several attempts were made on the part of other prominent professionals interested in the bonds between psychological and pedagogical perspectives, and as a consequence three distinct models of burnout were devised and set forth (Pines, Aronson, \& Kafry, 1981; Shirom, 1989). 


\subsection{Burnout Models}

\subsubsection{Maslach's Model}

Following Freudenberger's lead, Maslach (1982) managed to formulate an elaborate and well-grounded conceptualization of burnout, which still continues to feature as an unsurpassed model. To move in line with Maslach, it can be stated that burnout, as an extreme amount of listlessness, lethargy, and lassitude in laborers might arise in response to extreme occasions of 'emotional exhaustion, depersonalization and reduced personal accomplishment' (Maslach, 1993; Maslach \& Jackson, 1981; Maslach, Jackson, \& Leiter, 1996). Emotional exhaustion is said to be at work when one feels he/she has used up his/her entire emotional resources. Depersonalization, on the other hand, is claimed to occur when the individual commences to form negative and unsympathetic outlooks toward other people in his/her workplace. Yet, once the person starts to negatively assess his/her own work, and consequently feels dissatisfied with his/her performance, $s($ he) is said to be faced with another phenomenon referred to as reduced personal accomplishment.

The symptoms of extreme burnout, as Maslach, Jackson, and Leiter, (1996) contend, are evident when the individual reaches the point at which $\mathrm{s}(\mathrm{he})$ develops rather detached feelings toward others, complains about high levels of emotional fatigue and exhaustion, and depicts lower levels of high-quality performance. Yet, due care must be given to the way the salience of each of the three elements in the above trilogy of burnout dimensions is approached. In tandem with Maslach and Jackson (1982) emotional exhaustion is to be regarded as the starting point from which burnout is thought to stem, and hence the manner in which emotional exhaustion gives way to other two components of burnout, i.e. depersonalization and diminished self accomplishment is claimed to follow in a linear fashion.

\subsubsection{Pines's Model}

Another prominent model of burnout is the one formulated by Pines et al. (1981), who initially differentiated between what they referred to as tedium (the likely outcome of experiencing any type of pressure) and burnout (the result of being faced with a specific kind of pressure, which is mainly emotional). Nonetheless, in later revisions to the model, Pines and Aronson (1988) didn't move in line with this dichotomous view of tedium and burnout, and came to devise a three-fold model of burnout encompassing the three constituents of physical, emotional, and mental exhaustion. Physical exhaustion is marked by listlessness, chronic fatigue and feebleness or frailty that is liable to give rise to several health issues such as illnesses and improper eating and sleeping habits. Emotional exhaustion, as the name revels, has to do with major emotional vulnerabilities which, if not attended to, might bring about emotional breakdowns, sense of alienation, and even depression. Finally, mental exhaustion is the state in which the learner regards his/her work and life as dissatisfactory and futile, and hence this category of Pines's model is thought to be very much analogous to the third component of Maslach's (1982) taxonomy, i.e. reduced personal accomplishment introduced in the course of foregoing discussion.

\subsubsection{Shirom's Model}

The latest burnout model is the one put forth by Shirom (1989), which is mainly informed by Hobfoll's (1985/1986) line of argumentation holding that people are motivated to preserve the resources they value. Shirom's model features as another three-dimensional model that views burnout as the consequence of excessive demands put on the worker on the part of his/her career, which eventually leads to the exhaustion of the individual's physical, emotional, and cognitive energies. Thus, as Shirom and colleagues (Shirom, 2003; Shirom, Melamed, Toker, Berliner, \& Shapira, 2005) argue, burnout comprises the three interconnected aspects of physical fatigue, emotional exhaustion, and cognitive weariness. Physical fatigue pertains to lack of sufficient energy to deal with one's daily tasks. Emotional exhaustion, on the other hand, has to do with lack of enthusiasm to take care of affectionate tasks in the workplace, including the process of building and strengthening interpersonal relationships with workmates. The last component of Shirom's taxonomy, known as Cognitive weariness, is characterized by the individuals' difficulty with concentration and normal thinking. To sum it up, in tandem with what Shirom (2003) avers burnout is the cumulative consequence of all these three types of exhaustion being gradually formed in the individual throughout the passage of time, and not just the result of one single component being at work at one particular fraction of time.

\subsection{From Fixed General Intelligence to Non-Crystallized Emotional Intelligence}

Being of a rather elusive nature, the concept of intelligence has undergone different changes, from intelligence as a unidimensional concept (Binet, 1905, as cited in Martin, 1997) to intelligence as a multiple concept (Gardner, 1983), and finally to intelligence as an emotional notion (Salovey \& Mayer, 1990). The early designers of intelligence tests focused only on cognitive abilities such as memory and problem-solving. For example, Binet equated intelligence with the abilities of logic and language. In fact, in the first half of the 20th century, IQ tests were considered adequate measures of intelligence. Society also linked IQ scores to an individual's potential for success in life 
(Wechsler, 1958).

Current research has moved away from IQ scores as the only measure of intelligence. As early as 1920, Thorndike (as cited in Wechsler, 1958) hypothesized that true intelligence is composed of not only an academic component, but also of emotional and social components. Social intelligence, wrote Thorndike, is "the ability to understand and manage men and women, boys and girls - to act wisely in human relations" (p. 228).

Shanley, Walker and Foley (1971) held that social intelligence was distinct from academic intelligence, but they found little evidence to support social intelligence as a separate construct. The more recent writings and research of Gardner (1983) have added support to the concept of multiple intelligences. Gardner has proposed a model of at least 8 types of intelligence including spatial, musical, intrapersonal, interpersonal, bodily-kinesthetic, naturalistic, linguistic and logical-mathematical.

Further, while society has traditionally placed a great deal of weight on academic intelligence, Bar-On (1997) argued that emotional and social intelligences were better predictors of success in life. The term emotional quotient (EQ) was first coined by Bar-On (1988, as cited in Bar-On, 1997) as a counterpart to IQ, that is, to cognitive ability. Bar-On thought of EQ as representing a set of social and emotional abilities that help individuals cope with the demands of daily life. Salovey and Mayer (1990) had something to some extent different and more restricted in mind when they introduced the term emotional intelligence several years later. For them, EI concerned the way in which an individual processes information about emotion and emotional responses.

Emotional Intelligence as a now-well-established construct and a self-contained discipline was given birth through the attempts by several celebrated scholars and intellectuals with an assortment of psychological affiliations. The term EQ (emotional quotient) was initially coined by Bar-On in the early 1980s to differentiate it from its counterpart, i.e. cognitive intelligence (IQ) (Bar-On, 2000). In a presumably weighted proclamation by Mayer, Salovey, and Caruso (2000) the outbreak of the notion of emotional intelligence (this so-called tantalizing oxymoron) is associated with the invaluable work of Salovey and Mayer and hence with the publication of two seminal articles by them at the outset of 1990s (Mayer, Dipaolo, \& Salovey, 1990; Salovey \& Mayer, 1990). The fact that Salovey and Mayer are known as the main originators of the concept of emotional intelligence is also recapitulated by several other researchers among whom a reference can be made to McCrae (2000). Later popularization of EQ is however said to be indebted to Goleman's highly influential and illuminating attempts impressively amassed in his 1995 tome, entitled Emotional Intelligence (Goleman, 1995).

\subsection{Definitions of Emotional Intelligence}

As a multifaceted construct, emotional intelligence has been approached from a variety of diverse perspectives by its illustrious precursors, and hence a number of varied delineations have been put forth by these forerunners of the field of emotional intelligence, in an attempt to further elucidate what features the so-called emotionally intelligent individuals are supposed to possess. The most original definition of emotional intelligence is the one set forth by Salovey and Mayer (1989/1990) who define it as "the ability to monitor one's own and others' feelings and emotions, to discriminate among them and to use this information to guide one's thinking and actions" (p.189).

Goleman (1995, p.34), as the other prominent pioneer in the domain of emotional intelligence maintains, EQ encompasses "abilities such as being able to motivate oneself and persist in the face of frustrations; to control impulses and delay gratification; to regulate one's moods and keep distress from swamping the ability to think; to emphasize and to hope." Nonetheless, this definition might appear not to be utterly in tandem with Goleman's later reconceptualization of emotional intelligence as "the capacity for recognizing our own feelings and those of others, for motivating ourselves, and for managing emotions well in ourselves and in our relationships" (1998, p. 317).

Though a multitude of other definitions have thus far been proposed for the notion of EQ, it would suffice to wrap up this section with Bar-On's (1997b, p.14) frequently cited elucidation of emotional intelligence as "an array of noncognitive capabilities, competencies, and skills that influence one's ability to succeed in coping with environmental demands and pressures."

\subsection{Measures of Emotional Intelligence}

The history of theorizing on what the construct of emotional intelligence would look like has always proceeded hand in hand with another line of endeavor aiming at the provision of several operationalized measurement scales approaching the concept of emotional intelligence from a number of different angles. Though literature is replete with several attempts aimed at scrutinizing the construct of emotional intelligence, not all such rough and ready enterprises are worth giving in-depth deliberation in the current study.

Overall, in line with Mayer, Caruso, and Salovey (2000), three branches of emotional intelligence tests exist alternatively being referred to as ability, self-report, and observer or informant rating scales. The sample measures 
they then put forth as the major archetypes of each scale are: 1) their own renowned test (Mayer, Salovey, \& Caruso, 1997/1999) widely known as MEIS (Multifactor Emotional Intelligence Scale) which is ubiquitously cited as the paramount epitome of ability scales, 2) Bar-On's (1997) EQ-i and Cooper's (1996/1997) EQ-Map which are stated as the principal types of self-report measures, and 3) Boyatzis, Goleman, and Hay/McBer's (1999) Emotional Competence Inventory (ECI) that is known as the best example of third group of scales drawing mainly on observer (informant) responses.

As the main EQ scale used in the present study is Bar-On's Emotional Quotient Inventory (widely known as EQ-i), in the ensuing section a laconic account will be provided of a number of elemental features of this typical self-report measure of emotional intelligence, and each of its components will be briefly defined and elucidated.

\subsection{Bar-On's EQ-i}

First designed as an experimental scale for measuring the so-called emotional and social competence in the early 1980s (Bar-On, 1985, 1988), Emotional Quotient Inventory (EQ-i) was ultimately disseminated as an invaluable and highly pervasive measure of emotional intelligence in 1997. Though a plethora of EI scales had been publicized and promulgated prior to the appearance of Bar-On's (1997a) seminal work, EQ-i can be considered sui generis in that it is referred to as the primary EI test which is published by a psychological center. Furthermore, the additional factor that differentiates between Bar-On's scale and its other counterparts is the distinct nature of EQ-i which is widely known as a self-report measure (Bar-On, 2000).

The self-report test of emotional intelligence designed by Bar-On (1997b), is after submitting a firm measurement of "an array of noncognitive capabilities, competencies, and skills that influence one's ability to succeed in coping with environmental demands and pressures" (p.14). Its unabridged version is composed of 133 items normally being allotted something around forty minutes to fulfill and is said to be apposite to the age of seventeen and above. This scale is composed of five sections and fifteen separate subsections as follows:

1. Intrapersonal, consisting of five subcategories of emotional self awareness, assertiveness, self-regard, self-actualization, and independence

2. Interpersonal, encompassing the three sub-skills of empathy, interpersonal relationship, and social responsibility

3. Stress management, having as its subparts the two so-called categories of stress tolerance and impulse control

4. Adaptability, comprising the three divisions of problem solving, reality testing, and flexibility

5. General mood, entailing the two subscales of happiness and optimism.

Below are succinct delineations for each of the 15 subscales of EQ-i (based on Bar-On, 2000, pp.365-366):

Emotional Self-Awareness (ES) is the ability to recognize and understand one's emotions; Assertiveness (AS) is the ability to express feelings, beliefs, and thoughts, and to defend one's rights in a nondestructive manner; Self-Regard $(S R)$ is the ability to be aware of, understand, accept, and respect oneself; Self-Actualization (SA) is the ability to realize one's potential and to do what one wants to do, enjoy doing, and can do; Independence (IN) is the ability to be self-directed and self-controlled in one's thinking and actions and to be free of emotional dependency; Empathy $(E M)$ is the ability to be aware of, understand, and appreciate the feelings of others; Social Responsibility (RE) is the ability to demonstrate oneself as a cooperative, contributing, and constructive member of one's social group; Interpersonal Relationship (IR) is the ability to establish and maintain mutually satisfying relationships that are characterized by emotional closeness, intimacy, and by giving and receiving affection; Reality Testing (RT) is the ability to access the correspondence between what is internally and subjectively experienced and what externally and objectively exists; Flexibility (FL) is the ability to adjust one's feelings, thoughts, and behavior to changing situations and conditions; Problem Solving (PS) is the ability to identify and define personal and social problems as well as to generate and implement potentially effective solutions; Stress Tolerance (ST) is the ability to withstand adverse events, stressful situations, and strong emotions without "falling apart" by actively and positively coping with stress; Impulse Control (IC) is the ability to resist or delay an impulse, drive, or temptation to act, and to control one's emotions; Optimism (OP) is the ability "to look at the brighter side of life" and to maintain a positive attitude, even in the face of adversity; Happiness (HA) is the ability to feel satisfied with one's life, to enjoy oneself and others, and to have fun and express positive emotions.

\section{Method}

\subsection{Participants}

Participants of the current study were a total of 75 English teachers (37 males, 38 females) teaching at high schools 
in three cities of west Azerbaijan, Iran, namely Boukan, Mohabad and Miyandoab. A wide amount of variation was witnessed with regard to both the participants' ages and their years of experience; indeed, their age ranged between 22 and 45, and they had been actively involved in the teaching profession for 3-27 years.

\subsection{Instruments}

The research tools in the present study were two well-established questionnaires, i.e. Maslach Burnout Inventory-Educators Survey (Maslach, Jackson, \& Leiter, 1996) and Bar-On's EQ-i (1997), which were utilized for measuring participants' burnout and EI, respectively. In addition to these scales, a demographic form was also given to the participants, which asked about their age, teaching experience and gender.

\subsubsection{Burnout Scale}

As stated earlier, teacher burnout was measured using Maslach Burnout Inventory-Educator's Survey (MBI-ES) (Maslach, Jackson, \& Leiter, 1996). The scale is a 22-item self report instrument described in the literature as "the most widely used operationalization of burnout" (Lee \& Ashforth, 1996, p. 124). The MBI-ES consists of three subscales: Emotional Exhaustion (EE) (9 items), Depersonalization (DP) (5 items), and Personal accomplishment (UA) (8 items). Participants respond on a seven-point Likert-type scale, ranging from "never" (0) to "every day" (6). High scores on the EE and DP subscales and low scores on the PA subscale are characteristic of burnout. In this study, Cronbach's alpha reliability coefficients were $\alpha=.86$ for EE, $\alpha=.73$ for DP, and $\alpha=.79$ for PA. Table 1 shows the classification of the three sub-scales and their reliability.

\subsubsection{EI Scale}

To evaluate language teachers' EI, the researchers employed 'Bar-On's EI test' (Bar-On, 1997). It employs a 5-point response scale with a textual response format ranging from strongly disagree to strongly agree. This test includes 5 major scales and 15 subscales as follow:

1. Intrapersonal: (a) Emotional self-awareness, (b) Assertiveness, (c) Self-regard, (d) Self-actualization, (e) Independence.

2. Interpersonal: (a) Empathy, (b) Interpersonal-relationship, (c) Social responsibility

3. Adaptability: (a) Problem solving, (b) Reality testing, (c) Flexibility

4. Stress management: (a) Stress tolerance, (b) Impulse control

5. General mood: (a) Happiness, (b) Optimism

In the present study, a Persian version of the EQ test with 90 items was utilized. According to Samouei (2003, as cited in Alavinia, 2009), this test and its subscales do have reliability and validity in Iranian culture. To analyze the questionnaire in Iran, Samouei chose a group of 500 university students (aging from 18 to 40) in Tehran and analyzed the norms of the test. As she stated, the questionnaire has generally good internal consistency, test-retest reliability, and construct validity. In the present study reliability estimates for scales were $\alpha=0.78$ for intrapersonal; $\alpha=0.79$ for interpersonal, $\alpha=0.75$ for adaptability; $\alpha=0.83$ for stress management; and $\alpha=0.75$ for general mood. Table 2 shows the demarcation of the items relevant to different sub-scales of Bar-On's EQ-i.

\subsection{Design}

In this study the quantitative method was appropriate to examine the relationship between variables and to determine how much one variable or group of variables contributed to the prediction of another. In this correlational research, data about emotional intelligence and burnout were gathered from EFL teachers in order to assess their relationships. The predictor variable, EI and the criterion variable, burnout were assessed with self-reporting measures. The participants were also asked about their demographics including Age, Years of Teaching Experience and Gender. In addition, as a non-experimental design, the phenomena of teacher burnout and EI were examined as they occurred in the natural setting; that is, there was no manipulation of variables or modification of the situation under investigation. Nor was cause and effect established. Therefore, the intended design was ex-post-facto.

\subsection{Procedure}

Prior to data collection, the researchers obtained approval from the head of each high school. After the approval, the researchers along with school secretaries recruited teachers within the designated institutes. All subjects were informed of the purpose of the study, and the approximate time needed to complete the questionnaires (approximately 40 minutes). All teachers were assured that their participation would be anonymous and voluntary. It was also explained that the results would consist of group data and that individual participants and institutes would not be identified. This information was presented in an informed consent form that was handed out with the survey packet. The completion of the survey packet indicated implied consent and thus no signed consent form was 
returned. Participants were encouraged to keep the informed consent page for their records. Teachers were encouraged to contact the investigator if any questions or concerns arose as a result of their participation in the study. The participants took the questionnaires home, filled them out and submitted them to the secretaries of the schools within 10 days. Finally, in order to answer the research inquiry, the responses obtained from the questionnaires were tabulated and analyzed.

\subsection{Statistical Analysis}

The SPSS Pack 18.0 for Windows software was used to organize the raw data and conduct statistical analysis. Data entered on each participant included two scores from MBI-ES and Bar-On's EI test and three teacher characteristics (age, gender and teaching experience) obtained via the demographic data sheet. Different statistical analyses were utilized to evaluate the data and assess the relationship among the variables. To test the first and third hypotheses, a series of Pearson Product-Moment Correlations, for the second hypothesis, Regression analysis and, finally, for the last hypothesis a series of Independent Samples T-Tests were conducted.

\section{Results}

The descriptive statistics for the scales and demographics are provided in Table 3. To provide a more reader-friendly account, the research questions of the current study are discussed one by one.

\subsection{The Findings per Research Question}

\subsubsection{Research Question 1}

In order to examine research question one, Pearson Product Moment Correlation was run. As shown in Table 4, the results indicate that there were significant negative correlations between EI and Burnout $(r=-0.69, p<0.01)$. Therefore, the first null hypothesis indicating that there was no statistically significant relationship between burnout and emotional intelligence among Iranian EFL teachers was rejected.

\subsubsection{Research Question 2}

To analyze the data further, regression analysis was conducted. The results indicated that teachers' total score of EI is a negative predictor of the dependent variable, i.e. teachers' burnout $(\beta=-0.58, \mathrm{t}=-7.31, \mathrm{p}<.01, \mathrm{~F}=69.17)$ (see Table 5).

The results revealed that the model containing the total scores of the EI test can predict $48 \%$ of the teachers' burnout. The $\mathrm{R}$ value is 0.69 , which indicates the correlation coefficient between teachers' EI and burnout. The square is 0.48 , and this indicates that about $48 \%$ of the variation in teachers' burnout can be explained by taking their EI into account (see Table 6). Therefore, the null hypothesis indicating that EI cannot significantly predict burnout among EFL teachers was successfully rejected.

\subsubsection{Research Question 3A}

To examine the association between teachers' age and years of teaching experience, on the one hand and their EI and burnout, on the other, a series of Pearson Product Moment Correlations were run. The results in Table 7 show that there were significant positive correlations between EI and Years of Teaching Experience $(r=0.38, p<0.01)$, EI and Age $(\mathrm{r}=0.25, \mathrm{p}<0.01)$ and significant negative correlations between Burnout and Years of Teaching Experience $(\mathrm{r}$ $=-0.35, \mathrm{p}<0.01)$, and Burnout and Age $(\mathrm{r}=-0.32, \mathrm{p}<0.01)$. Therefore, hypothesis 2 indicating that Teachers' age and years of teaching experience had no statistically significant relationship with burnout and emotional intelligence among Iranian EFL teachers was rejected.

\subsubsection{Research Questions 3B \& 3C}

To explore whether there were significant EI and burnout differences among EFL teachers with respect to gender, a series of independent t-test analyses were conducted. The results indicated that, with respect to gender, teachers were not significantly different on their scores on EI $(t=0.42$, df $=73, p>0.05)$, but they were significantly different on their burnout scores $(\mathrm{t}=-2.22, \mathrm{df}=73, \mathrm{p}<0.05)$, with female teachers outscoring their male counterparts. In other words, female teachers were more prone to burnout (see Table 8 ). Therefore, null hypothesis $3 \mathrm{~B}$ indicating that there was no significant difference in EFL teachers' EI with respect to gender failed to be rejected. However, null hypothesis $3 \mathrm{C}$ that postulated no significant difference in EFL teachers' burnout with respect to gender was confidently rejected.

\subsection{Discussion}

This study was an attempt to investigate the would-be association between emotional intelligence as a coping resource and burnout phenomenon among a group of Iranian EFL teachers in high schools. Furthermore, differences in EI and burnout scores were examined with respect to demographic variables namely, teacher age, years of 
teaching experience and gender.

\subsubsection{Research Question $1 \& 2$}

The present study sought to investigate, in the first place, if there is any relationship between teachers' burnout and their EI, and whether EI could be a potential predictor of burnout. The results indicated that there was a statistically significant negative correlation between burnout and EI. The size of this correlation indicated that the higher the teachers' EI, the less likely they were to experience burnout in their profession. Further, the findings showed EI could significantly predict burnout among the EFL teachers. This is in accordance with previous theoretical studies on the role of emotional intelligence in burnout, though these are limited where teachers are concerned, and quite sparse in the foreign/second language context. Those who score high on emotional intelligence skills are expected to deal more effectively with environmental demands and pressures associated with occupational stress and health outcomes than those who score low on EI (Brackett, Palomera, Mojsa-Kaja, Reyes, \& Salovey, 2010; Mendes, 2002). In a study carried out with secondary teachers in England, it was observed that teachers' EI predicts level of burnout (Brackett, et al, 2010), confirming a study where teachers' ability to regulate emotions was related to their perceived levels of depersonalization, self-realization, and emotional wear (Mendes, 2002). A study conducted by Salovey, Bedell, Detweiler, and Mayer (1999) discovered that individuals who are able to regulate their emotional states are healthier because they "accurately perceive and appraise their emotional states, know how and when to express their feelings and can effectively regulate their mood states" (p. 161). This suggests that there is a direct connection between emotional intelligence skills and physical as well as psychological health (Tsaousis \& Nikolaou, 2005). Emotionally intelligent individuals can cope better with life's challenges and control their emotions more efficiently (Taylor, 2001). Harrod and Scheer (2005) also held that emotional intelligence is the driving force behind the factors that affect personal success and everyday interactions with others.

Similarly, when it comes to teaching English as a foreign language in high schools, teachers who are more emotionally intelligent are more likely to cope with different stressors (e.g., job insecurity due to lack of tenure status, work overload, students' low motivation and lack of sufficient time). On the other hand, when teachers pay less attention to their own emotions and those of others, they cannot survive the demanding conditions in these organizations and tend to collapse under the burden of the stressors. They may look at things as if they are tougher than they really are. This belief engenders high levels of stress, and consequently precipitates teacher burnout.

\subsubsection{Research Question 3}

Regarding the third research question - the relationship between teachers' EI and burnout with demographic variables - the results indicated a positive correlation between EFL teachers' EI and years of teaching experience, as well as age. In other words, teachers' emotional experience tends to increase over time and with every year of teaching. This is consistent with previous research that indicated EI is acquired and developed through learning and repeated experience (e.g. Alavinia, 2011a/b), in contrast to IQ, which is considered relatively to be stable and unchangeable (Goleman, 1995). Bar-On (2000) also posited that EI develops over time and that it can be improved through training, programming and therapy.

With reference to the influence of gender on teachers' EI, it was found that there was no significant difference between emotional intelligence of male and female teachers. These findings confirmed the results reported by Hopkins and Bilimoria (2008) and Rastegar and Memarpour (2009); yet they were in conflict with the findings of Ciarrochi, Chan and Bajgar (2001), which indicated that there were significant differences between females and males, with females reporting higher EI levels. However, one plausible reason for this conflict may be related to cultural and environmental factors. Another reason for this lack of gender difference is that female teachers might underrate their competence or men might overrate theirs or both. Whether there were no real gender differences, or the real gender differences could not be detected by self-report questionnaires in the present findings has to await further studies.

Further, findings of the present study indicated a significant negative correlation between EFL teachers' age and their burnout. In other words, teachers' burnout tends to decline over time. This is consistent with previous research that demonstrated that age is an important factor in predicting teacher burnout. Substantial evidence has shown that younger teachers have a higher propensity to experience total burnout (Farber, 1984) and emotional exhaustion and/or depersonalization than older teachers (Anderson \& Iwanicki, 1984; Schwab \& Iwanicki, 1982). One explanation for this result can be based on Huston's (1989) additional finding that younger teachers, due to their age and lack of saleable skills, feel enmeshed with few alternative possibilities. Due to lack of experience, these teachers might get demoralized in a demanding situation. Consequently, their level of burnout might rise.

Regarding teaching experience, it was found that more experienced teachers were less vulnerable to burnout than less experienced ones. These findings were in line with those reported by Capel (1987) and Pierce and Molloy 
(1990), while in conflict with the findings of Benham Tye and O'Brien (2002) which contended that older and more experienced teachers were more prone to the accumulated effects of stress, and therefore, more liable to suffer higher levels of burnout than the younger and less experienced workforce. However, there were a host of studies that did not yield statistically significant associations with any of the burnout dimensions and teaching experience overall (Gold, Roth, Wright \& Michael, 1991; Schwab \& Iwanicki, 1982). Regarding the findings of the present study, one explanation is perhaps experience cures nervousness, disorganization, and various stressors associated with novice teaching in an EFL context which is replete with anxiety and feelings of uneasiness, frustration, self-doubt and apprehension for both teachers and learners. Moreover, more experienced teachers may have a comfort in what they do and, therefore, feel less negative and chronic stress that may lead to burnout.

Finally, the results of the present study showed that there were significant burnout differences among EFL teachers with respect to gender. In other words, female teachers' burnout level was significantly higher than that of males. These findings are in accordance with those of Borg and Riding (1991) and Lachman and Diamant (1987), but in contrast with Anderson and Iwanichi's (1984) findings which indicated significantly higher levels of burnout among male teachers. In the present study, female teachers' higher burnout level may be attributed to work overload due to their double dose of responsibility both in language institutes as teachers and in the home as housekeepers. However, additional studies are clamored to further explore factors related to gender as possible influences on burnout ratings.

\section{Conclusion and Implications}

In essence, the yielded results of the current study lead to the conclusion that enhancing teachers' EI tends to have a positive influence on diminishing their burnout. This in turn may lead to amelioration of teachers' well-being, pro-social behavior, motivation and teaching effectiveness and accordingly students' achievement. The findings also indicate that EFL teachers, particularly older and more experienced ones, would do well to take a closer look at their own emotional skills and to systematically reassess these skills through an emotionally intelligent lens, as a result of which they are likely to be more successful at reducing the level of burnout. This research extends past findings on teacher EI and burnout, and contributes to better understanding of these phenomena and how they are related especially in an EFL context. These results can be used to develop both practical and research endeavors aimed at reducing teacher burnout and improving teacher EI.

Based on the results of this study, school-based social and emotional learning programs should be developed for EFL teachers. Kremenitzer (2005) stated: "an increase in a teacher's emotional intelligence significantly impacts on student learning in a powerful way both in academic and interpersonal domains" (p. 6). Greenberg (2002) also argued that emotionally intelligent teachers are less vulnerable to stress and might easily retrieve healthy information and action tendency within emotions, and avail themselves of this information to better react to stressors as well as to inspire adaptive action.

To efficiently deal with teacher burnout, based on the finding of the present study, EFL teachers, especially younger ones and those with fewer years of teaching experience, should develop skills in monitoring their stress levels. Research by Cockburn (1996) concluded that the first step for teachers in reducing stress is to develop their awareness of stress levels. Only when a teacher understands and monitors his or her stress levels can steps be taken to control the level of stress. It is also hoped that the results from this study will assist teacher educators and school administrators in creating the conditions necessary for their teachers to work with minimal stress. Finally, based on the findings of the present study, it is not fair to judge a teacher based on only one of his/her aspects. Each teacher with certain kinds of demographics is unique and no over-generalized statements can be made about him/her. Therefore, teacher educators can assist teachers to overcome their problems better by knowing how varied teachers are and how these differences result in diverse performances and perceptions in the classroom.

\section{References}

Alavinia, P. (2009). Emotional engineering through the application of fuzzy logic: Enhancing emotional intelligence by raising awareness of emotions, Unpublished PH.D Dissertation. Allame Tabatabaee University, Tehran, Iran.

Alavinia, P. (2011a). Emotional Engineering through the Application of Fuzzy Logic: Enhancing Emotional Intelligence by Raising Awareness of Emotions. Germany: VDM Verlag.

Alavinia, P. (2011b). Toward the Refutation of Herrnstein and Murray's Maxims: Is (Emotional) Intelligence Acquirable and Modifiable through Schooling? Germany: Lambert Academic Publishing.

Anderson, M. B. G., \& Iwanicki, E. F. (1984). Teacher motivation and its relationship to burnout. Educational Administration Quarterly, 20(2), 109-132. http://dx.doi.org/10.1177/0013161X84020002007

Bar-On, R. (1985). The development of an operational concept of psychological well-being. Unpublished doctoral dissertation (first draft). Rhodes University, South Africa. 
Bar-On, R. (1988). The development of a concept of psychological well-being. Unpublished doctoral dissertation (final draft). Rhodes University, South Africa.

Bar-On, R. (1997a). The Emotional Quotient Inventory (EQ-i): A test of emotional intelligence. Toronto: Multi-Health Systems.

Bar-On, R. (1997b). BarOn Emotional Quotient Inventory (EQ-i): Technical manual. Toronto: Multi-Health Systems.

Bar-On, R. (2000). Emotional and social intelligence: Insights from the emotional quotient inventory (EQ-i). In: Bar-On, R., \& Parker, J. D. (Eds.), The handbook of emotional intelligence (pp. 363-388). Jossey-Bass, San Francisco.

Bar-On, R. (2002). Bar-On Emotional Quotient Inventory (EQ-i): Technical manual. Toronto, Canada: Multi-Health Systems.

Bar-On, R. (2007). The conceptual aspects of the Bar-On model (the theory). [Online] Available: http://www.reuvenbaron.org/bar-on-model/conceptualaspects.php (Jul 11, 2011)

Benham Tye, B., \& O’Brien, L. (2002). The teacher shortage: Why are experienced teachers leaving the profession? Phi Delta Kappan, 84(1), 24-32.

Borg, M. G. (1990). Occupational stress in British educational settings: A review. Educational Psychology, 10, 103-126. http://dx.doi.org/10.1080/0144341900100201

Borg, M. G., \& Riding, R. J. (1991). Occupational stress and satisfaction in teaching. British Educational Research Journal, 17(3), 263-281. http://dx.doi.org/10.1080/0141192910170306

Boyatzis, R. E., Goleman, D., \& Hay/McBer. (1999). Emotional competence Inventory. Boston: Hay/McBer Group.

Brackett, M. A., Palomera, R., Mojsa-Kaja, J., Reyes, M. R., \& Salovey, P. (2010). Emotion-regulation ability, burnout, and job satisfaction among British secondary-school teachers. Psychology in the Schools, 47(4), 406-417.

Capel, S. A. (1987). The incidence of and influence on stress and burnout in secondary school teachers. British Journal of Educational Psychology, 57, 279-288. http://dx.doi.org/10.1111/j.2044-8279.1987.tb00857.x

Chan, D. W. (2006). Emotional intelligence and components of burnout among Chinese secondary school teachers in Hong Kong. Teaching and Teacher Education, 22, 1042-1054. http://dx.doi.org/10.1016/j.tate.2006.04.005

Ciarrochi, J., Chan, A. Y. C., \& Bajgar, J. (2001). Measuring emotional intelligence in adolescents. Personality and Individual Differences, 31, 1105-1119. http://dx.doi.org/10.1016/S0191-8869(00)00207-5

Cockburn, A. D. (1996). Primary teachers' knowledge and acquisition of stress relieving strategies. British Journal of Educational Psychology, 66, 399-410. http://dx.doi.org/10.1111/j.2044-8279.1996.tb01205.x

Cooper, R. K. (1996/1997). EQ Map. San Francisco: AIT and Essi Systems.

Farber, B. A. (1984). Teacher burnout: Assumptions, myths, and issues. Teachers College Record, 86, 321-338.

Farber, B. A. (1991). Crisis in education: Stress and burnout in the American teacher. San Francisco: Jossey-Bass, Inc.

Freudenberger, H. (1974). Staff burn-out. Journal of Social Issues, 30(1), 159-165. http://dx.doi.org/10.1111/j.1540-4560.1974.tb00706.x

Harrod, R. N., \& Sheer, D. S. (2005). An exploration of adolescence emotional intelligence in relation to demographic characteristics. Adolescence, 40(159), 503-513.

Heibert, B., \& Farber, I. (1984). Teacher stress: A literature survey with a few surprises. Canadian Journal of Education, 9(1), 14-27. http://dx.doi.org/10.2307/1494447

Hobfoll, S. E. (1985). Personal and social resources and the ecology of stress resistance. In P. Shaver (Ed.), Review of Personality and Social Psychology (pp. 265-290). New York: Sage.

Hobfoll, S. E. (1986). The ecology of stress and social support among women. In S. E. Hobfoll (Ed.), Stress, social support and women (pp. 3-14). Washington, DC: Hemisphere.

Hopkins, M. M., \& Bilimoria, D. (2008). Social and emotional competencies predicting success for male and female executives. Journal of Management Development, 27(1), 13-35. http://dx.doi.org/10.1108/02621710810840749

Huston, J. (1989). Teacher burnout and effectiveness: A case study. Education, 110(1), 70-78.

Gardner, H. (1983). Frames of mind: the theory of multiple intelligence. New York: Basic Books. 
Ghanizadeh, A., \& Moafian, F. (2009a). The role of EFL teachers' emotional intelligence in their success. ELT Journal, 64(4), 424-435. http://dx.doi.org/10.1093/elt/ccp084

Ghanizadeh, A., \& Moafian, F. (2009b). The relationship between Iranian EFL teachers' sense of self-efficacy and their pedagogical success in language institutes. Asian EFL Journal, 13(2), 249-272.

Gohm, L. C, Corser, C. G., \& Dalsky, J. D. (2005). Emotional intelligence under stress: Useful, unnecessary, or irrelevant? Personality and Individual Differences, 39, 1017-1028. http://dx.doi.org/10.1016/j.paid.2005.03.018

Gold, Y., Roth, R. A., Wright, C. R., \& Michael, W. B. (1991). The relationship of scores on the Educators Survey, a modified version of the Maslach Burnout Inventory, to three teaching-related variables for a sample of 132 beginning teachers. Educational and Psychological Measurement, 51, 429-438. http://dx.doi.org/10.1177/0013164491512017

Goleman, D. (1995). Emotional intelligence. New York: Bantam.

Goleman, D. (1998). Working with Emotional Intelligence. New York: Bantam Books.

Greenberg, L. S. (2002). Emotion-focused therapy. Washington, DC: American Psychological Association.

Kremenitzer, J. P. (2005). The emotionally intelligent early childhood educator: self-reflective journaling. Early Childhood Education Journal, 33(1), 3-9. http://dx.doi.org/10.1007/s10643-005-0014-6

Kyriacou, C. (1980). Stress, health and schoolteachers: A comparison with other professions. Cambridge Journal of Education, 10, 154-159. http://dx.doi.org/10.1080/0305764800100304

Kyriacou, C. (2001). Teacher stress: Directions for future research. Educational Review, 53(1), 27-35. http://dx.doi.org/10.1080/00131910120033628

Kyriacou, C., \& Pratt, J. (1985). Teacher stress and psychoneurotic symptoms. British Journal of Educational Psychology, 55, 61-64. http://dx.doi.org/10.1111/j.2044-8279.1985.tb02607.x

Kyriacou, C., \& Sutcliffe, J. (1978a). A model of teacher stress. Educational Studies, 4, 1-6. http://dx.doi.org/10.1080/0305569780040101

Kyriacou, C., \& Sutcliffe, J. (1978b). Teacher stress: Prevalence, sources, and symptoms. British Journal of Educational Psychology, 48, 159-167. http://dx.doi.org/10.1111/j.2044-8279.1978.tb02381.x

Lachman, R., \& Diamant, E. (1987). Withdrawal and restraining factors in teachers' turnover intentions. Journal of Occupational Behaviour, 8, 219-232. http://dx.doi.org/10.1002/job.4030080304

Lee, R. T., \& Ashforth, B. E. (1996). A meta-analytic examination of the correlates of the three dimensions of job burnout. Journal of Applied Psychology, 81(2), 123-133. http://dx.doi.org/10.1037/0021-9010.81.2.123

Martin, O. (1997). La mesure en psychologie de Binet athurstone, 1900-1930. Revue De Synthese, 4(4), 457-493. http://dx.doi.org/10.1007/BF03181359

Maslach, C. (1982). Burnout: The cost of caring. Englewood Cliffs, NJ: Prentice-Hall, Inc.

Maslach, C. (1993). Burnout: A multidimensional perspective. In W. B. Schaufeli, C. Maslach, \& T., Marek (Eds.), Professional burnout: Recent developments in theory and research (pp. 19-32). Washington: Taylor and Francis.

Maslach, C., \& Jackson, S. E. (1981). The measurement of experienced burnout. Journal of Occupational Behavior, 2, 99-113. http://dx.doi.org/10.1002/job.4030020205

Maslach, C., Jackson, S. E., \& Leiter, M. P. (1996). Maslach burnout inventory manual (3rd edition). Palo Alto, CA: Consulting Psychologist Press.

Maslach, C., \& Schaufeli, W. B. (1993). Historical and conceptual development of burnout. In W. B. Schaufeli, C. Maslach, \& T. Marek (Eds.), Professional burnout: Recent developments in theory and research (pp. 1-18). Washington, DC: Taylor \& Francis.

Mayer, J. D. (1999). Emotional intelligence: Popular or scientific psychology? Washington, DC: American Psychological Association.

Mayer, J. D., Caruso, D., \& Salovey, P. (2000a). Emotional intelligence meets traditional standards for an intelligence. Intelligence, 27(4), 267-298. http://dx.doi.org/10.1016/S0160-2896(99)00016-1

Mayer, J. D., Caruso, D., \& Salovey, P. (2000b). Selecting a measure of emotional intelligence: The case for ability scales. In R. Bar-On \& J. D. A. Parker (Eds.), The handbook of emotional intelligence: Theory, development, assessment, and application at home, school, and in the workplace (pp. 320-342). San Francisco, CA: Jossey-Bass.

Mayer, J. D., DiPaolo, M. T., \& Salovey, P. (1990). Perceiving affective content in ambiguous visual stimuli: A 
component of emotional intelligence. Journal of Personality Assessment, 54, 772-781. http://dx.doi.org/10.1080/00223891.1990.9674037

Mayer, J. D., Salovey, P., \& Caruso, D. R. (1997). The Emotional IQ Test [CD-Rom]. Needham, MA: Virtual Knowledge.

Mayer, J. D., Salovey, P., \& Caruso, D. R. (1999a). MSCEIT Item Booklet (Research Version 1.1). Toronto, Canada: Multi-Health Systems.

Mayer, J. D., Salovey, P., \& Caruso, D. R. (1999b). Working Manual for the MSCEIT (Research Version 1.1). Manuscript in preparation, available from Multi-Health Systems, Toronto, Canada.

McCrae, R. R. (2000). Emotional intelligence from the perspective of the five-factor model of personality. In R. Bar-On \& J. D. A. Parker (Eds.), The handbook of emotional intelligence: Theory, development, assessment, and application at home, school, and in the workplace (pp. 263-276). San Francisco, CA: Jossey-Bass.

Mendes, J. (2002). The Relationship between emotional intelligence and occupational burnout in secondary school teachers. Dissertation Abstracts International, 63(10), 4951A.

Milstein, M. M., \& Farkas, J. (1988). The overstated case of educator stress. Journal of Educational Administration, 26, 232-249. http://dx.doi.org/10.1108/eb009951

Moafian, F., \& Ghanizadeh, A. (2009). The relationship between Iranian EFL teachers' emotional intelligence and their self-efficacy in language institutes. System, 37, 708-718. http://dx.doi.org/10.1016/j.system.2009.09.014

Paese, P. (2003). Impact of professional development schools: Pre-service through induction. Teacher Education, 25(1), 83-88.

Pierce, C. M. B., \& Molloy, G. N. (1990). Psychological and biographical differences between secondary school teachers experiencing high and low levels of burnout. British Journal of Educational Psychology, 60, 37-51. http://dx.doi.org/10.1111/j.2044-8279.1990.tb00920.x

Pines, A. M., \& Aronson, E. (1988). Career burnout: Causes and cures. New York: The Free Press.

Pines, A. M., Aronson, E., \& Kafry, D. (1981). Burnout: From tedium to personal growth. New York: The Free Press.

Rastegar, M., \& Memarpour, S. (2009). The relationship between emotional intelligence and self-efficacy among Iranian EFL teachers. System, 37, 700-707. http://dx.doi.org/10.1016/j.system.2009.09.013

Rydell, A-M., \& Henricsson, L. (2004). Elementary school teachers' strategies to handle externalizing class room behavior. A study of relations between perceived control, teacher orientation and strategy preferences. Scandinavian Journal of Psychology, 45, 93-102. http://dx.doi.org/10.1111/j.1467-9450.2004.00384.x

Salovey, P., Bedell, B. T., Detweiler, J. B., \& Mayer, J. D. (1999). Coping intelligently: Emotional intelligence and the coping process. In C. R. Snyder (Ed.), Coping: The psychology of what works (pp. 141-164). New York: Oxford Psychology Press.

Salovey, P., Bedell, B. T., Detweiler, J. B., \& Mayer, J. D. (2000). Current directions in emotional intelligence research. In M. Lewis, \& J. M. Haviland-Jones (Eds.), Handbook of emotions (2nd ed., pp. 504-520). New York: Guilford.

Salovey, P., \& Mayer, J. D. (1990). Emotional intelligence. Imagination, Cognition, and Personality, 9, 185-211.

Schwab, R. L., \& Iwanicki, E. F. (1982). Who are burned out teachers? Educational Research Quarterly, 7(2), 5-16.

Shanley, L. A., Walker, R. E., \& Foley, J. M. (1971). Social intelligence: A concept in search of data. Psychological Reports, 29, 1123-1132.

Shirom, A. (1989). Burnout in work organizations. In C. L. Cooper, \& I. Robertson (Ed.), International Review of Industrial and Organizational Psychology (pp. 25-48). New York: Wiley.

Shirom, A. (2003). The effects of work-related stress on health. In M. J. Schabracq, J. A. M. Winnubst, \& C. L. Cooper (Eds.), Handbook of work and health psychology (2 ${ }^{\text {nd }}$ ed., pp. 63-83). New York: Wiley.

Shirom, A., Melamed, S., Toker, S., Berliner, S., \& Shapira, I. (2005). Burnout, mental and physical health: A review of the evidence and a proposed explanatory model. International Review of Industrial and Organizational Psychology, 20, 269-309.

Taylor, G. J. (2001). Low emotional intelligence and mental illness. In J. Ciarrochi, \& J.P. Forgas (Eds), Emotional intelligence in everyday life: A scientific inquiry (pp. 67-81). Philadelphia, PA: Taylor \& Francis.

Tsaousis, I., \& Nikolaou, I. (2005) Exploring the relationship of emotional intelligence with physical and 
psychological functioning. Stress and Health, 21, 77-86. http://dx.doi.org/10.1002/smi.1042

Tye, B. B., \& O’Brien, L. (2002). Why are experienced teachers leaving the profession? Phi Delta Kappan, 84(1), 24-33.

Wechsler, D. (1958). Measurement and appraisal of adult intelligence. Baltimore, MD: Williams \& Wilkins Company. http://dx.doi.org/10.1037/11167-000

Table 1. Classification of Different Items of Burnout Scale

\begin{tabular}{ccc}
\hline Sub-Scales & Items & Cronbach's Alpha \\
\hline Emotional Exhaustion & $1,4,9,10,15,16,18,20,22$ & .86 \\
\hline Personal accomplishment & $3^{*}, 6^{*}, 7^{*}, 12^{*}, 13^{*}, 17^{*}, 19^{*}, 21^{*}$ & .79 \\
\hline Depersonalization & $2,5,8,11,14$ & .73 \\
\hline
\end{tabular}

${ }^{*}$ Scored in reverse order

Table 2. Classification of Different Items of EI Scale

\begin{tabular}{ll}
\hline \multicolumn{1}{c}{ Scales } & Items \\
\hline Emotional Self-Awareness & $81^{*}, 66,51,36^{*}, 21^{*}, 6$ \\
\hline Assertiveness & $90^{*}, 75^{*}, 60,45^{*}, 30,15^{*}$ \\
\hline Self-Regard & $85,70,55,40^{*}, 25,10$ \\
\hline Self-Actualization & $80^{*}, 65,50^{*}, 35^{*}, 20^{*}, 5$ \\
\hline Independence & $78^{*}, 63^{*}, 48^{*}, 33^{*}, 18^{*}, 3$ \\
\hline Empathy & $89,74,59,44,29,14$ \\
\hline Social Responsibility & $88,73,58^{*}, 43,28,13$ \\
\hline Interpersonal Relationship & $83,68,53,38,23,8$ \\
\hline Reality Testing & $82^{*}, 67^{*}, 52^{*}, 37^{*}, 22^{*}, 7$ \\
\hline Flexibility & $87^{*}, 72^{*}, 57,42,27^{*}, 12^{*}$ \\
\hline Problem Solving & $76,61^{*}, 46,31,16,1$ \\
\hline Stress Tolerance & $79^{*}, 64^{*}, 49,34^{*}, 19^{*}, 4$ \\
\hline Impulse Control & $86^{*}, 71^{*}, 56^{*}, 41^{*}, 26^{*}, 11^{*}$ \\
\hline Optimism & $84^{*}, 69,54,39,24,9$ \\
\hline Happiness & $77^{*}, 62,47,32,17^{*}, 2^{*}$ \\
\hline
\end{tabular}

*Scoring is done in the reverse order in these questions

Table 3. Descriptive Statistics for Age, Teaching Experience, EI and Burnout

\begin{tabular}{llcccc}
\hline Variables & $\mathrm{N}$ & Minimum & Maximum & Mean & Std. Deviation \\
\hline YTE & 75 & 3.00 & 25.00 & 7.22 & 4.59 \\
AG & 75 & 22.00 & 45.00 & 29.08 & 6.12 \\
Br & 75 & 6.00 & 79.00 & 32.24 & 16.86 \\
EI & 75 & 245.00 & 423.00 & 338.68 & 35.31 \\
\hline
\end{tabular}

Note. $\mathrm{YTE}=$ Years of Teaching Experience, $\mathrm{Ag}=\mathrm{Age}, \mathrm{EI}=$ Emotional Intelligence, $\mathrm{Br}=$ Burnout.

Table 4. Correlation between EI and Burnout $(n=75)$

Burnout

$$
\text { EI }
$$

$-0.69 * *$

**. Correlation is significant at the 0.01 level (2-tailed). 
Table 5. The Results of Regression Analysis for Teachers' EI and their Burnout

\begin{tabular}{|c|c|c|c|c|c|c|c|}
\hline \multicolumn{2}{|c|}{ Model } & \multicolumn{2}{|c|}{$\begin{array}{l}\text { Unstandardized } \\
\text { Coefficients }\end{array}$} & $\begin{array}{r}\begin{array}{r}\text { Standardized } \\
\text { Coefficients }\end{array} \\
\operatorname{Beta}(\beta)\end{array}$ & $\mathrm{t}$ & $\mathrm{F}$ & Sig. \\
\hline \multirow[t]{2}{*}{$1^{\mathrm{a}}$} & (Constant) & 13.32 & 12.64 & & 10.93 & 69.17 & .000 \\
\hline & EI & -.30 & .03 & -.58 & -7.31 & & .000 \\
\hline
\end{tabular}

a. Dependent Variable: Burnout

Table 6. $\mathrm{R}^{2}$ table for EI as the predictor of teachers' burnout

\begin{tabular}{ccccc}
\hline Model & $\mathrm{R}$ & $\mathrm{R}^{2}$ & Adjusted $\mathrm{R}^{2}$ & Std. Error of the Estimate \\
\hline $1^{\mathrm{a}}$ & .69 & .48 & .48 & 12.92 \\
\hline
\end{tabular}

a. Predictor: (Constant), EI

Table 7. Correlation between Age and Years of Teaching Experience \& EI and Burnout $(n=75)$

\begin{tabular}{lcc}
\hline & Age & Years of Teaching Experience \\
\hline EI & $0.39^{* *}$ & $0.37^{* *}$ \\
\hline Burnout & $-0.37^{* *}$ & $-0.33^{* *}$
\end{tabular}

**. Correlation is significant at the 0.01 level (2-tailed).

Table 8. Comparison of Means, St. Deviations and T-Values of Teachers' EI, and Burnout scores by Gender (N=75).

\begin{tabular}{ccccccc}
\hline \multicolumn{2}{c}{$\begin{array}{c}\text { Male } \\
(\mathrm{N}=37)\end{array}$} & \multicolumn{2}{c}{$\begin{array}{c}\text { Female } \\
(\mathrm{N}=38)\end{array}$} \\
\hline Scales & $\mathrm{M}$ & $\mathrm{SD}$ & $\mathrm{M}$ & $\mathrm{SD}$ & $\mathrm{t}$ & $\mathrm{P}$ \\
\hline EI & 343.89 & 48.78 & 339.81 & 31.92 & $.42^{\mathrm{a}}$ & .66 \\
Burnout & 29.32 & 19.56 & 38.28 & 15.11 & $-2.22^{*}$ & .02 \\
\hline
\end{tabular}

${ }^{a} \mathrm{p}>0.05$ (2-tailed). Insignificant

$* \mathrm{p}<0.05$ (2-tailed). Significant 